\title{
TRUNNIONOSIS- What we should know as an Orthopaedic Surgeon
}

\author{
Nishikant Kumar* and Andalib Kasani \\ Consultant Orthopaedics and Joint Replacement Surgeons, India \\ Submission: April 08, 2020; Published: April 16, 2020 \\ *Corresponding author: Nishikant Kumar, Consultant Orthopaedics and Joint Replacement Surgeons, Patna, India
}

\section{Introduction}

The main question is what is Trunnionosis and what do we need to know as a surgeon. So trunnionosis is basically metallosis. It is the generation of metallic debris from a combination of motion at head on neck junction and an electrochemical corrosion $[1,2]$. Trunnion is part of the femoral stem where head gets engaged [1]; Corrosion of this part is called Trunnionosis. Taper is the slotted part of head which fits into trunnion of stem; corrosion of this part is called Taperosis (Figure 1).

Trunnionosis is basically a electrochemical corrosion and metallosis due to micromotion; and both are basically synergestic and generates huge amount of metallic particles [2]. It causes the same adverse local tissue reaction as metal on metal heads as in ALVAL, Pseudotumours. Trunionosis also causes osteolysis ${ }^{3}$.

Trunnion is an independent source of metal ion [3-5]. In Rush Clinical Series, 27 patients of THR were revised for advanced local tissue reaction secondary to head neck corrosion with metal on poly bearings. The revision rates because of trunnionosis was 4.3\% between 2009-2013.

\section{Clinical Presentation}

A patient of trunionosis usually presents with pain, limp and swelling of the affected hip $[1,3,6]$. The mean age of presentation is usually $4.3 y r s$ after surgery $[2,6]$ (ranges $<1$ to $26 y r s$ ), typically $2-3 y r s$. The plain radiographs should be done first to check the implant position, type of implant. Osteolysis is frequently seen in $26 \%$ of cases [6], primarily at medial calcar, greater trochanter, periacetabular region. When a patient presents with a painful hip, we need to rule out infection as well. On blood investigation $50 \%$ patients of metallosis present with elevated ESR or CRP which is not an effective way in ruling out infection. On aspiration of these affected hips grey colour fluid which is mostly acellular that only confuses further with infection. For investigations we can rely on synovial fluid testing for CRP and Alpha defensin in the synovial fluid and that will rule out infection.
You must be suspicious of Trunnionosis in MOM total hips, Modular neck Total hip, MOP hip with CO-CR stem [1,5-7]. If there is suspicion of trunionosis in a metal on poly bearing surface there should be no metal in blood [6-8]. The metal serum levels should not be elevated. If a patient has trunionosis they will have elevated cobalt and chromium and characteristically cobalt $>>$ chromium [6-10]. For diagnosis of trunion metal on poly serum levels of $>1 \mathrm{ng} / \mathrm{ml}$ is bad. For metal on metal hip implants serum levels of $>6 \mathrm{ng} / \mathrm{ml}$ is abnormal, and these patients need a close followup. A well-functioning metal on poly bearing should have $<1 \mathrm{ppb}$ $[6,8,9]$. Metal artifact reduction sequence MARS MRI will help find things that are classic for metallosis like fluid collection around stem and pseudomass [8-10] (Figure 2) We need to see whether the symptoms are due to metal sensitivity. A lot of patients are exposed to metallic debris and tend to develop a metal sensitivity.

\section{Treatment}

So, when we get a patient with painful hip two to three years post op, MARS MRI suspicious, ruled out infection and they have elevated cobalt; The question is whether to revise it or not. On revision we need to deal with difficult soft tissue dissection and debris. Looking at the acetabular component, if it is well positioned acetabular components, it may be retained. On the other hand, if it is modular MOM, we can change the acetabular liner to Poly or Ceramic [7-10]. Total Synovectomy should be done, stem is retained in most of cases and taper grossly cleaned (Figure 3). Only remove the stem if there is macroscopic damage and mechanically stable taper linkage is not possible. In the neck component, it is necessary to get rid of metallic debris as much possible and change the interface to ceramic bearing with titanium sleeve, so that the combination is not with a cobalt chrome head but to a titanium sleeve which is a much favourable combination. The result is a decrease in serum metallic levels. However, these patients are at a high risk for dislocation, mostly due to a lot of soft tissue destruction so in some cases constrained liner or Dual mobility cup can be applied. 


\section{Orthopedics and Rheumatology Open Access Journal (OROAJ)}

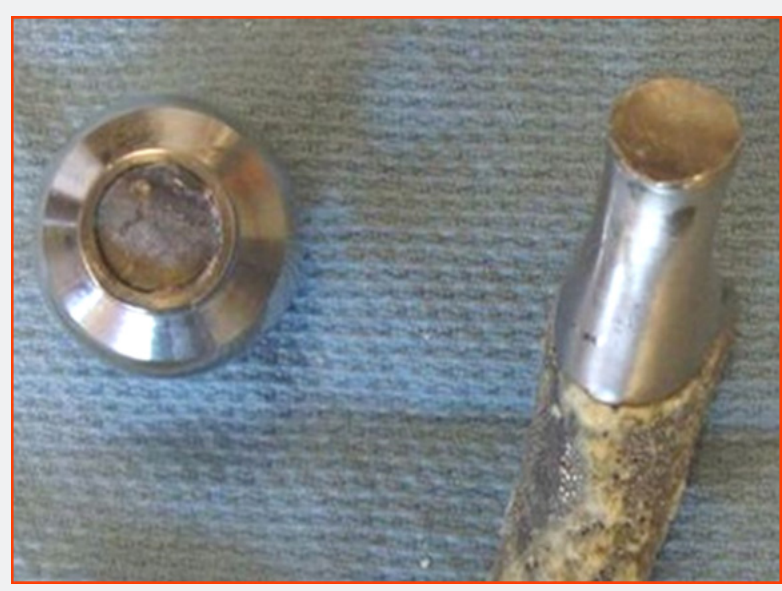

Figure 1: Trunnion and Taper.

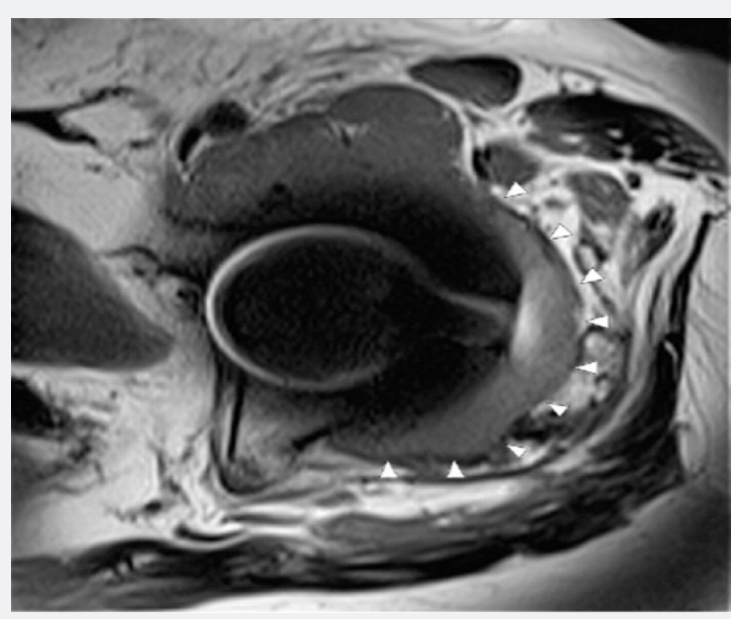

Figure 2: MARS Imaging in a Painful hip; Trunnionosis.

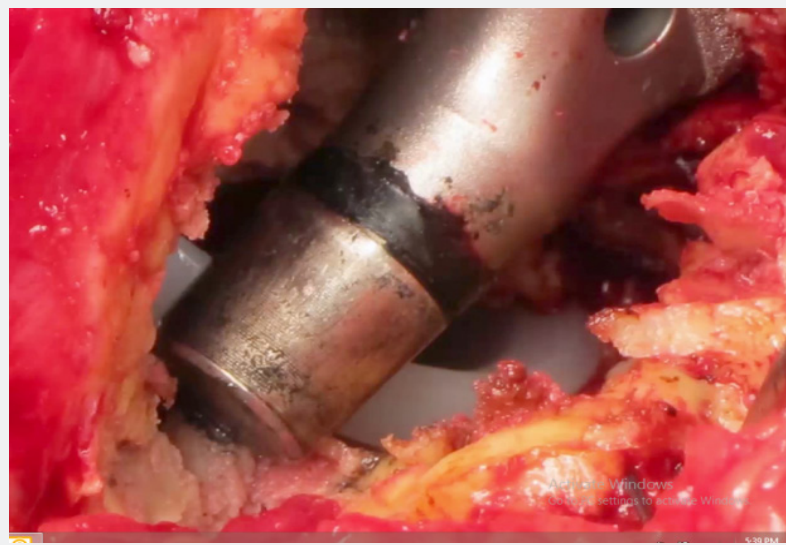

Figure 3: Typical lesion of Tunnionosis.

\section{Trunion Designs}

Main aim is to achieve stability of ball on the neck. The neck should be thick and long so that there is deep engagement within head [2,7-9]. A head with long neck line has more lever arm which would give more opportunity of motion of head on neck and it is the micromotion of head on neck that sets off the synergistic reaction combining with electrochemical corrosion. So, we need 
a stable connection between the head and the neck. Also, the material matters. Thus, CoCr on CoCr is not ideal, CoCr on titanium is better, titanium on ceramic is even better. A good taper is a long and thick, shorter neck length heads, with titanium and oxinium as taper materials $[6,7,9]$. Whether the head size matters or not is not clear. A large head size causes more friction [4-6]. Oxinium as head material is more stable and corrosion resistant and very less metal deposition is seen.

Current evidence suggests that the cause of Trunionosis occurs at surgery. Correct surgical technique is important to avoid trunionosis. Even in ideal conditions $25 \%$ of implantations are not in correct position. So, we need to have good exposure. A clean and dry taper is essential. Even drops of fat or drops of blood can impact how securely it is fixed. Seat the headfirst without any impaction. The direction of impaction should be co-linear $[4,7,8,10]$. The force of impaction should be $2000 \mathrm{~N}$. And avoid damage to taper during revision.

\section{Summary}

Trunionosis is Not an easy diagnosis. The metal levels $>1 \mathrm{ng} /$ $\mathrm{ml}$ abnormal in metal on poly in THR. MRI with MARS sequences are helpful in diagnosis. Stem retention with head/liner exchange to ceramic with titanium sleeve is required in most cases. We need to evaluate the soft tissue and instability and be mindful while impacting the final head on stem.

\section{References}

1. Lombardi AV, Barrack RL, Berend KR, Cuckler JM, Jacobs JJ, et al. (2012) The Hip Society: algorithmic approach to diagnosis and management of metal-on-metal arthroplasty. J Bone Joint Surg Br 94(11): 14-18.
2. Lavernia CJ, Iacobelli DA, Villa JM, Jones K, Gonzalez JL, et al. (2015) Trunnion-head stresses in THA: are big heads trouble? J Arthroplasty 30(6): 1085-1088.

3. Drummond J, Tran P, Fary C (2015) Metal-on-metal hip arthroplasty: a review of adverse reactions and patient management. J Funct Biomater 6(3): 486-499.

4. Dyrkacz RM, Brandt JM, Ojo OA, Turgeon TR, Wyss UP (2013) The influence of head size on corrosion and fretting behaviour at the headneck interface of artificial hip joints. J Arthroplasty 28(6): 1036-1040.

5. Tan SC, Teeter MG, Del Balso C, Howard JL, Lanting BA (2015) Effect of taper design on trunnionosis in metal on polyethylene total hip arthroplasty. J Arthroplasty 30(7): 1269-1272.

6. Hussenbocus S, Kosuge D, Solomon LB, Howie DW, Oskouei RH (2015) Head-neck taper corrosion in hip arthroplasty.Biomed Res Int 2015: 758123.

7. Gill IP, Webb J, Sloan K, Beaver RJ (2012) Corrosion at the neck-stem junction as a cause of metal ion release and pseudotumor formation. J Bone Joint Surg Br 94(7): 895-900.

8. Lindgren JU, Brismar BH, Wikstrom AC (2011) Adverse reaction to metal release from a modular metal-on-polyethylene hip prosthesis. J Bone Joint Surg Br 93(10): 1427-1430.

9. Porter DA, Urban RM, Jacobs JJ, Gilbert JL, Rodriguez JA, et al. (2014) Modern trunnions are more flexible: a mechanical analysis of THA taper designs. Clin Orthop Relat Res 472(12): 3963-3970.

10. Kwon YM, Xia Z, Glyn-Jones S, Beard D, Gill HS, et al. (2009) Dosedependent cytotoxicity of clinically relevant cobalt nanoparticles and ions on macrophages in vitro. Biomed Mater 4(2): 025018.

\section{Your next submission with Juniper Publishers will reach you the below assets}

- Quality Editorial service

- Swift Peer Review

- Reprints availability

- E-prints Service

- Manuscript Podcast for convenient understanding

- Global attainment for your research

- Manuscript accessibility in different formats ( Pdf, E-pub, Full Text, Audio)

- Unceasing customer service

Track the below URL for one-step submission https://juniperpublishers.com/online-submission.php 